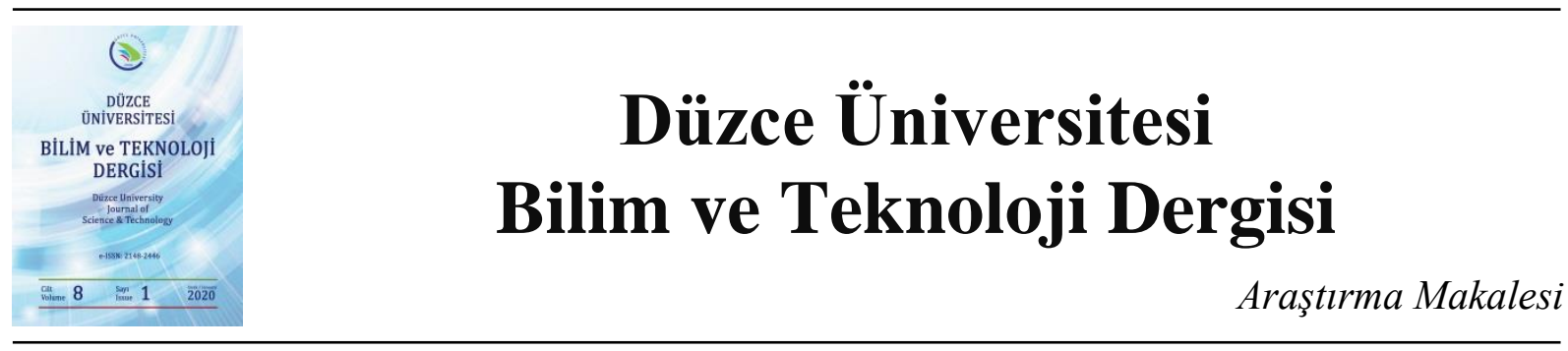

\section{Jeotermal Enerji Kaynaklı Ara Isıtmalı Organik Rankine Çevriminin Konvansiyonel ve İleri Ekserji Analizi}

\author{
D Abid USTAOĞLU ${ }^{\mathrm{a}, *}$ \\ ${ }^{a}$ Makine Mühendisliği Bölümü, Mühendislik Fakültesi, Bartın Üniversitesi, Bartın, TÜRKIYE \\ * Sorumlu yazartn e-posta adresi: austaoglu@bartin.edu.tr; abidusta@hotmail.com
}

DOI: $10.29130 /$ dubited.570330

\begin{abstract}
ÖZET
Ekserji analiz metodu üretilen faydalı işin belirlenmesinde önemli bir araçtır. Ancak sadece ekserji analizi ile çevrimde kullanılan komponentler arasındaki etkileşimin, yani komponentte oluşan ekserji yıkımının komponentin kendisinden mi yoksa etkileşimde bulunduğu diğer komponentlerden mi kaynaklandığını veya sistemin gerçek geliştirilme potansiyelini, yani sistemde ve komponentlerde oluşan ekserji yıkımlarından ne kadarının önlenebileceğini belirlemek mümkün değildir. Bu yüzden ileri ekserji analiz metodu kullanılmaktadır. $\mathrm{Bu}$ çalışmada, iş akışkanı olarak R152a kullanan jeotermal destekli ara 1sıtmalı organik Rankine çevriminin gerçek geliştirilme potansiyelinin ve çevrimde bulunan komponentler arasındaki etkileşimin belirlenmesi için konvansiyonel ve ileri ekserji analizleri yapılmıştır. Sistemin geliştirme potansiyelini belirlemek için ekserji yıkımının önlenebilir/kaçınılamaz kısımları belirlenmiştir. Komponentler arasındaki etkileşimin detaylıca belirlenmesi için de içsel/dışsal ekserji yıkımları belirlenmiştir. Ayrıca yoğuşturucu ve buharlaştıııcı basınçlarının sistem performansı üzerindeki etkisi incelenmiştir. Ekserji ve enerji verimleri sırasıyla \%50.69 ve \%14.04 olarak hesaplanmıştır. İleri analiz sonuçlarına göre sistem çok büyük oranda kaçınılmaz (\%95.04) ve içsel (\%86.6) ekserji yıkımlarına sahiptir. Buradan sistemin sadece \%5'lik bir geliştirme potansiyeli olduğu görülmektedir. Türbinlerdeki tersinmezliklerin tamamı dışsal iken, pompa ve buharlaştırıcıdaki tersinmezlikler bu komponentlerin kendilerinden kaynaklanmaktadır. Toplam içsel ekserji yıkımının en yüksek yüzdesi yaklaşık \%93 ile buharlaştırıcıda meydana gelmiş̧ir. En yüksek ekserji yıkımı buharlaştırıcıda olmakla birlikte bu bileşendeki geliştirme potansiyeli sıfırdır. Türbinlerdeki önlenebilir ekserji yıkımı, toplam önlenebilir kısmın \%85.34'üne eşittir. Sonuçlar, sistemin performansını geliştirmek için öncelikle odaklanılması gereken komponetlerin alçak ve yüksek basınç türbinleri olduğu göstermektedir.
\end{abstract}

Anahtar Kelimeler: Jeotermal, Enerji, Ekserji, İleri Ekserji, Ara ısıtmall, Organik Rankine Çevrimi

\section{Conventional and Advanced Exergy Analysis of Geothermal Energy Powered Reheat Organic Rankine Cycle}

\begin{abstract}
The exergy method is an important tool that can show the useful work generated through the process. However, it cannot explain the interaction among the components, namely the reason of the exergy destruction arisen from the component's itself or from the other components or cannot estimate the actual improvement potential,
\end{abstract}


namely how much part of the exergy destruction falling into the part of avoidable and unavoidable exergy destructions. Therefore, advanced exergy analysis method has been used fort the detail evaluation. In this study, conventional and advanced exergy analysis have been carried out on a geothermal powered reheat organic Rankine cycle using R152a as a working fluid. The avoidable/unavoidable parts of the exergy destraction rate was obtained to decide the imporvement potential of the system and endogeious/exogenious parts of the exergy destruction rate was decided for carring out a detail analysis on the interaction among the components. Moreover, the effects of the condenser and evaporator pressures on the system performance were invesitigated. The exergy and energy efficiencies were calculated to be $50.69 \%$ and $14.04 \%$, respectively. According to the advanced exergy analysis results, system has a large share of unavoidable (95.04\%) and endogenious (86.6\%) exergy destruction rates. It is seen that only a 5\% of an improvement potential of the system exists. While whole exergy destruction rate in the turbines is falling into the part of exogenious part, the exergy destruction rates of the pump and evaporator results from the components' themselves. The largest share of the endogenious exergy destrucation rate occurs in the evaporator with 93\%. In conjunction with that the largest exergy decstruction occuring in the evaporator, its improvement potential is zero. The exergy destruction rates in the turbines is equal to $85.34 \%$ of the total avoidable part of the destruction. The results show that the low- and high-pressure turbines are the primary components to focus on to improve the system performances.

Keywords: Geothermal, Energy, Exergy, Advanced Exergy, Reheat, Organic Rankine Cycle

\section{GİRIS}

Günümüzde teknolojinin gelişimi ve sanayileşme ile birlikte enerjiye olan talep hızla artmaktadır. $\mathrm{Bu}$ gelişmelere bağlı olarak karbon salınımını arttıran ve sınırlı miktarda bulunan kömür, petrol ve doğalgaz gibi fosil kaynakların kullanımı gittikçe yaygınlaşmaktadır. Fosil kaynakların kullanımından kaynaklı enerji problemleri artarken, gelişmiş ve gelişmekte olan ülkeler alternatif enerji kaynaklarına yönelmişlerdir. Günümüzde güneş, rüzgâr, dalga, biyokütle ve jeotermal gibi çeşitli yenilenebilir enerji kaynakları güç üretimi ve soğutma çevrimleri gibi birçok termodinamik çevrimde enerji kaynağı olarak kullanılmaktadır. Ülkemiz jeotermal enerji kaynağı olarak dünyadaki en zengin potansiyele ülkelerden biridir. Ancak bu enerjinin büyük bir kısmı sadece sıcak su ihtiyacı ve mesken 1sıtmada kullanılmaktadır. Bu 1sı kaynağının daha faydalı bir şekilde kullanılması için Rankine çevrimli bir güç santralinin kullanılması uygun bir yaklaşım olacaktır. Organik Rankine çevrimleri düşük sıcaklıktaki enerji kaynaklarının daha etkin kullanılmasıyla avantaj sağlamaktadır [1]. Burada kaynama noktası sudan daha düşük olan çeşitlik organik akışkanlar çevrimde iş akışkanı olarak kullanılmaktadır. Bu sistemlerin verimleri çeşitli yöntemlerle arttırılabilmektedir. Organik Rankine çevrimine (ORÇ) ara 1sıtmanın eklenmesiyle sistem verimi artmaktadır. İkinci yasa analizi, tersinmezliklerin yerini, miktarı ve kaynağını belirlemek için önemli bir yoldur. Literatürde çeşitli organik rankine çevrimlerinin termodinamiğin birinci ve ikinci yasa analizini içeren birçok çalışma mevcuttur.

Şahin vd. [2] organik Rankine çevriminde farklı tip akışkanların kullanılması durumda türbin giriş sıcaklığı ve basıncının birinci yasa verimi, ikinci yasa verimi ve bileşenlerin ekserji yıkımları üzerindeki etkisini araştırmışlardır. Yapılan analiz sonucunda en iyi akışkanın R290 olduğu belirlenmiştir. Bunun yanında türbin giriş basıncının ve sıcaklığının sırasıyla $2000 \mathrm{kPa}$ ve $150{ }^{\circ} \mathrm{C}$ olması durumunda kuru tip akışkan olan R600a için toplam ekserji yıkımının \%90'nın yoğuşturucuda gerçekleştiğini bulmuşlardır. Gogoi ve Talukdar [3] ara 1sıtmalı, geri beslemeli birleşik buhar çevrimi ve su/Li-Br absorpsiyonlu sisteminin ekserji analizini yapmışlardır. İkinci yasa analizi sonucunda optimum performansın 150 bar kazan basıncı, jeneratör, yoğuşturucu, buharlaştırıcı ve soğurucu 
sıcaklıklarının sırasıyla $80^{\circ} \mathrm{C}, 37.5^{\circ} \mathrm{C}, 15^{\circ} \mathrm{C}$ ve $35^{\circ} \mathrm{C}$ olması durumunda gerçekleştiğini belirlemişlerdir. Ayrıca soğutma sistemindeki ekserji yıkımının en yüksekten aza doğru jeneratör, soğurucu, yoğuşturucu ve buharlaştırıcı şekilde olduğunu bulmuşlardır. Khaliq ve Kaushik [4] ara 1sıtmalı Brayton/Rankine birleşik güç sisteminin ikinci yasa temelli termodinamik analizini yapmışlardır. Güç üretimini, enerji verimini, ekserji yıkımını ve ekserji verimini belirlemişlerdir. Basınç oranı, çevrim sıcaklık oranı, ara 1sıtmaların sayısı ve çevrim basınç düşüşünün kombine çevrim performansı üzerindeki etkisini araştırmışlardır. Sistemdeki toplam ekserji yıkımının yarısının yanma odasında olduğunu bulmuşlardır. Birleşik çevrim veriminin ve güç çıktısının orta seviyede bir basınç oranında en yüksek değerini alırken, iki ara 1sıtma kullanılması durumunda hızla artıp daha fazla ara 1sıtma kullanılması durumunda ise hızla azaldığı gözlemlenmiştir. Gang vd. [5] düşük yoğunlaştırma oranına sahip birleşik parabolik yoğunlaştırıcılı ve rejeneratörlü organik Rankine çevriminin birinci yasa analizini yapmışlardır. Rejeneratör sıcaklığının toplam kollektör verimi, elektrik verimi ve ORÇ’nin verimi üzerindeki etkisini araştırmışlardır. Analiz sonuçları rejenerasyon yapılması ORÇ’nin verimine pozitif etki yaparken, birinci sıradaki kollektörlerin ortalama çalışma sıcaklığındaki artıştan dolayı kollektör verimine negatif etki yaptığını göstermektedir. Bu nedenle rejenerasyon eklendiğinde toplam elektrik veriminin de değerlendirilmesi gerekir. Rejenerasyonlu ORÇ sisteminin elektrik verimi \%8.6 iken (Güneş radyasyonu $750 \mathrm{~W} / \mathrm{m}^{2}$ için) bu değer rejenerasyonsuz sistemin veriminden yaklaşı $\% 5$ daha büyüktür. Konvansiyonel analiz metodu yardımıyla tersinmezliklerin hangi komponentte olduğu ve miktarı belirlenebilir. Fakat bileşenler arasındaki etkileşim açıklanamaz ve gerçek geliştirme potansiyeli belirlenemez. Bu nedenle konvansiyonel yaklaşım, sistemin optimize edilebilmesi eksik bir yaklaşım olabilir. Daha detaylı analiz yapabilmek için ileri ekserji analizi metodu geliştirilmiştir [6]. İleri ekserji analiz metodunda ekserji yıkımları önlenebilir/kaçınılamaz ve içsel/dışsal kısımlara ayrılmaktadır. Böylelikle termodinmik sistem daha ayrıntılı olarak incelenmiş olur. [7,8]

İleri ekserji analizi birçok termodinamik çevrime uygulanmıştır. Bunlar, kaskad [9,10] absorpsiyonlu [11,12], ejektörlü [13] ve buhar sıkıştırmalı [14] gibi soğutma sistemleri, düzlemsel güneş kollektörleri [15], birleşik güç sistemleri [16,17], çimento fabrikaları [18], sıkıştırılmış hava kullanılan enerji depolama sistemleri [19], gaz çevrimleri [20] ve Organik Rankine çevrimler [21] gibi sistemlerdir. Ustaoğlu vd. [13] atık 1sı kaynaklı ejektörlü soğutma sisteminin konvansiyonel ve ileri ekserji analizini yapmışlardır. İş akışkanı olarak kuru (R600a), 1slak (R134a ve R152a) ve izantropik (R290, R141b ve $\mathrm{R} 142 \mathrm{~b})$ olmak üzere üç farklı akışkan tipi kullanmış ve sistemin geliştirme potansiyelini tespit edilmiştir. Sonuç olarak, sistemin performansının gelişmesi için hangi komponente öncelik verilmesi gerektiği soğutucu akışkana göre değiştiği gözlemlenmiştir. Soğutucu akışkan R134a kullanıldığı durumda sistemde geliştirilme potansiyeli en yüksek komponent ejektör iken, R600a için jeneratör olduğunu vurgulanmıştır. Petrakopoulou vd. [16] birleşik Brayton/Rankine güç santralinin ileri ekserji analizini yapmışlardır. Brayton çevrimindeki türbin ve buhar çevrimindeki yüksek basınç türbini hariç, santraldeki komponentlerde ekserji yıkımlarının çoğu kaçınılmaz yıkım olarak gerçekleşmiştir. Idrissa ve Boulama [17] birleşik Brayton/Brayton güç çevriminin ileri ekserji analizini yapmışlardır. Yanma odası çıkış sıcaklığının, alt ve üst çevrimin basınç oranlarının sistem performansı üzerindeki etkisini incelemişlerdir. En büyük ekserji yıkımının yanma odasında olduğunu ve bu tersinmezliğin büyük oranda kaçınılamaz ve içsel kısımlara ait olduğunu bulmuşlardır. Ayrıca yanma odası çıkış sıcaklığındaki $600 \mathrm{~K}$ 'lik artışın toplam ekserji yıkımında bir azalmaya yol açtığını tespit etmişlerdir. Fallah vd. [20] dört faklı gaz türbin sistemini karşılaştırmışlardır. Bunlar basit gaz türbini (SGT), evaporatif hava soğutmalı gaz türbini (EVGT), buhar enjeksiyonlu gaz türbini (STIG) ve buhar enjeksiyonlu, evaporatif hava soğutmalı gaz türbini (ESTIG). Bu karşılaştırmayı konvansiyonel ekserji analiz metodunu kullanarak yapmışlardır ve ESTIG sisteminin dizayn için en uygun sistem olduğuna karar vermişlerdir. İleri ekserji analiz metodunu kullanarak sistemin daha detaylı termodinamik 
analizini gerçekleştirmişlerdir. Maksimum net iş çıkışı şartlarında optimizasyon önceliğinin sırasıyla türbin, yanma odası, kompresör ve atık 1sı buhar jeneratörü şeklinde olduğunu belirtmişlerdir.

Ayrıca basınç oranı, bağıl nem ve çevre sıcaklığının sistem performansı üzerindeki etkisini araştırmışlardır. Literatürde organik Rankine çevriminin ileri ekserji analizi ile ilgili sınırlı sayıda çalışma vardır [21-27]. Hepsi de tek bir akışkanın analizini gerçekleştirmişlerdir.

Gökgedik vd. [22] Denizli'de bulunan Bereket Jeotermal Güç Santrali'nin gerçek değerlerini kullanarak ileri ekserji analizini yapmışlardır. Santralde iki ayrı ORÇ olup ikisinde de iş akışkanı olarak n-Pentane kullanılmaktadır. Sonuç olarak türbin hariç bütün komponentlerdeki önlenebilir ekserji yıkımının kaçınılmaz kısımdan daha yüksek olduğunu bulmuşlardır. Ayrıca sistemin ekserji verimini \%9.60 olarak hesaplamışlar ve sistemdeki iyileştirmelerle bu verimin yaklaşı \%11'e çıkartılabileceğini tespit etmişlerdir. Galindo vd. [28] içten yanmalı bir motorun atık 1sısını kullanan ORÇ’yi ileri ekserji analiz metodunu kullanarak termodinamik açıdan incelemişlerdir. İş akışkanı olarak etanolü kullanmışlardır. Konvansiyonel ekserji analizine göre sistemdeki en yüksek tersinmezlik kazanda gerçekleşirken, ileri ekserji analizi metoduna göre ise geliştirme önceliğinin sırasıyla türbin, pompa, yoğuşturucu ve kazan şeklinde olduğunu vurgulanmışdır. Nami vd. [21] jeotermal kaynaklı ORÇ sisteminin konvansiyonel ve ileri ekserji analizlerini yapmışlardır. Sistemde iki farklı çevrim olup çevrimlerde izopentan ve izobütan kullanılmıştır. Konvansiyonel ekserji analizine göre en fazla yıkım jeneratörlerde ve yoğuşturucuda olduğu görülmüsşür. İleri ekserji analizi sonuçlara göre ise jeneratörlere ve türbinlere yoğunlaştırılması gerektiğini belirtmişlerdir.

ORÇ’nin ileri ekserji analizi ile ilgili çalışmalar basit ORÇ ve rejeneratörlü sistemlere yoğunlaşmıştır. Ara 1sıtmalı ORÇ sisteminin ileri ekserji analizin değerlendirilmesiyle ilgili herhangi bir çalışmaya rastlanmamıştır. Bu çalışmada, jeotermal kaynaklı ara 1sıtmalı organik Rankine çevriminin teorik incelemesi gerçekleştirilmiştir. Sistemin konvansiyonel ve ileri ekserji analizleri sslak tip akışkan olan R152a için yapılmıştır. Yoğuşturucu basıncı, buharlaştırıcı basıncı ve türbin giriş sıcaklığının toplam ekserji yıkımı, sistemin enerji ve ekserji verimleri üzerindeki etkisi araştırılmıştır. Ayrıca komponentlerin önlenebilir/kaçınılamaz ve içsel/dışsal ekserji yıkımları hesaplanmıştır. Çalışmanın ana amacı, yoğuşturucu ve buharlaştırıcı basıncı gibi parametrelerin sistem performansı üzerindeki etkisini araştırmak, komponentlerin geliştirme potansiyellerini belirlemek ve komponentler arasındaki ilişkiyi ortaya koymaktır.

\section{SISTEM TANITIMI}

Şekil 1.'de çalışmada incelenen sistemin şematik görünümü verilmiştir. Termofiziksel, çevresel (düşük küresel ısınma potansiyeli, sıfır ozon incelme potansiyeli) ve yanıcılık-parlayıcılık (düşük yanıcılık ve parlayıcılık) özelliklerinden dolayı bu çalışmada iş akışkanı olarak R152a seçilmiştir [29]. 1 noktasındaki doymuş sıvı fazındaki iş akışkanı pompa yardımıyla yoğuşturucu basıncından buharlaştırıcı basıncına sıkıştırılmaktadır. Buharlaştırıııdan geçen akışkan jeotermal kaynak suyundan 1S1 alıp kızgın buhar fazında yüksek basınç türbinine girer. Yüksek basınç türbininden ara 1sıtma basıncına kadar genişletilen iş akışkanı tekrar buharlaştırıcıya girer ve burada 1sı alarak alçak basınç türbinine gönderilir (5 ve 3 noktasındaki sıcaklıklar aynıdır). R152a sonrasında alçak basınç türbininde yoğuşturucu basıncina genişletilir ve yoğuşturucuya girer. Yoğuşturucudan geçerken 1sısını soğutma suyuna vererek doymuş sıvı fazında pompaya girer. Böylece çevrim tamamlanmış olur. 


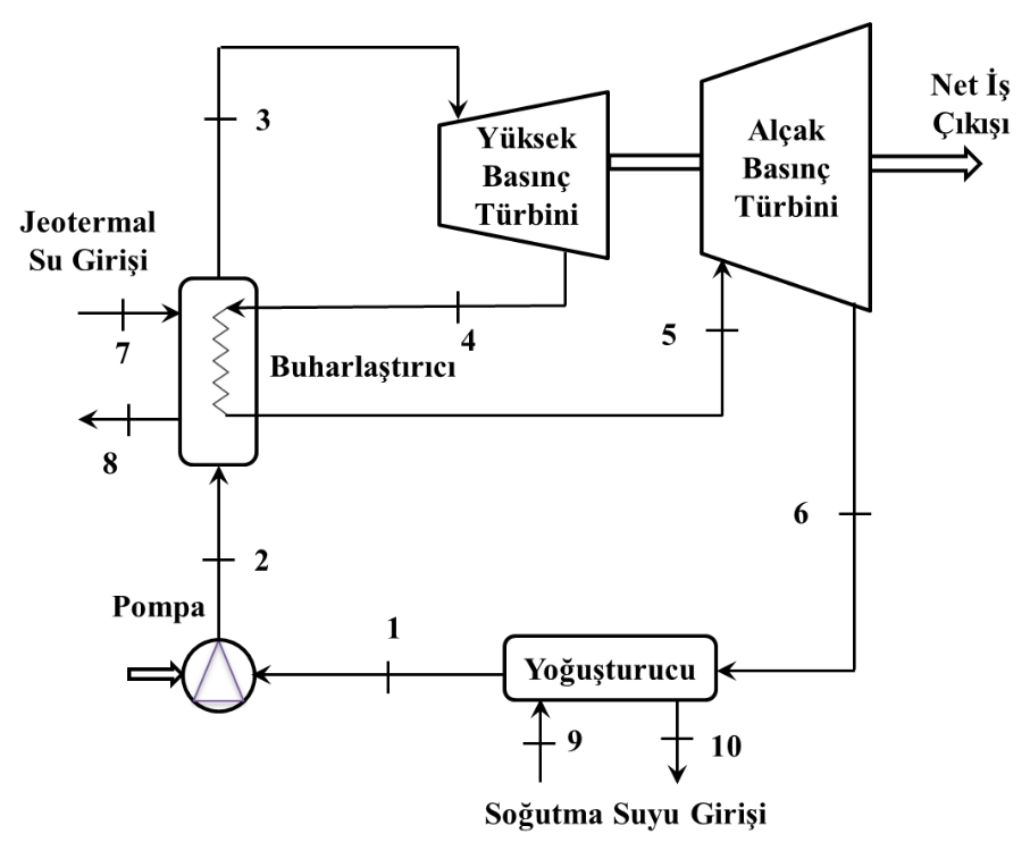

Şekil 1. Ara ısıtmalı organik Rankine çevriminin şematik görünümü

\section{TERMODINAMIK ANALIZ}

Tüm çalışma boyunca Şekil 1'de gösterilen ara 1sıtmalı organik Rankine çevrimi (AIORÇ) göz önünde bulundurulacaktır. Bu sistemin ana elemanları yoğuşturucu, pompa, buharlaştırıcı, alçak ve yüksek basınç türbinleridir. Çevrimin termodinamik analizi Mühendislik Denklem Çözücüsü (EES) yardımıyla yapılmıştır. Ayrıca analizde şu kabuller yapılmıştır:

1-) Bütün prosesler kararlı şartlardadır.

2-) Çevreden ve çevreye olan 1sı transferleri, sistem boyunca akışkanın dolaştırıldığı bağlantı boruları, buharlaştırıcı ve yoğuşturucudaki basınç kayıpları ihmal edilmiştir.

3-) Pompa girişindeki organik iş akışkanı doymuş sıvı fazındadır.

4-) Potansiyel ve kinetik enerji değişimleri ihmal edilmiştir.

5-) Ölü nokta sıcaklığı ve basıncı sırasıyla $101.325 \mathrm{kPa}$ ve $27^{\circ} \mathrm{C}$ olarak kabul edilmiştir.

\section{A. KONVANSIYYONEL EKSERJI ANALİZi}

Jeotermal enerji kaynaklı AIORÇ sistemi termodinamiğin birinci ve ikinci yasası dikkate alınarak modellenmiş ve bu yasalar sistemdeki her bir bileşene uygulanmıştır. Kinetik ve potansiyel enerjilerin ihmal edildiği durumda genel kütle, enerji ve ekserji denge denklemleri şu şekilde ifade edilebilir: [30], [31]

$\sum \dot{\mathrm{m}}_{\text {giren }}=\sum \dot{\mathrm{m}}_{\text {çlkan }}$

Termodinamiğin birinci yasası enerjinin korunumu olarak ifade edilir. Aşağıdaki denklemde sürekli akışlı açık sistemler için enerji korunumu denklemi gösterilmiştir [32,33].

$\dot{\mathrm{Q}}+\sum(\dot{\mathrm{m} h})_{\text {giren }}=\dot{\mathrm{W}}+\sum(\dot{\mathrm{m} h})_{\text {çıkan }}$ 
Kimyasal, kinetik ve potansiyel ekserjilerin ihmal edildiği durumda kararlı bir proses için bir kontrol hacmindeki ekserji denkliği şu şekilde yazılabilir: [31-34]

$\dot{\mathrm{E}} \mathrm{x}_{\mathrm{Q}}-\dot{\mathrm{E}} \mathrm{x}_{\mathrm{W}}=\sum(\dot{\mathrm{m}} \varepsilon)_{c_{\mathrm{l}} \mathrm{kan}}-\sum(\dot{\mathrm{m}} \varepsilon)_{\text {giren }}+\dot{\mathrm{E}} \mathrm{x}_{\mathrm{ylk} \text { Im }}$

Burada;

$\dot{\mathrm{E}} \mathrm{x}_{\mathrm{ylkım}}=\mathrm{T}_{0} \dot{\mathrm{S}}_{\text {uretim }}$

Ayrıca $\dot{E} x_{Q}, \dot{E} x_{W}$ ve $\varepsilon$ sırasıyla 1 sının ekserjisi, işin ekserjisi ve termomekanik ekserjiyi (akış ekserjisi) göstermektedir. Bu ifadeler şöyle gösterilebilir: [30]

$\dot{\mathrm{E}} \mathrm{x}_{\mathrm{Q}}=\dot{Q}\left(\frac{\mathrm{T}-\mathrm{T}_{0}}{\mathrm{~T}}\right)$

$\dot{\mathrm{E}} \mathrm{x}_{\mathrm{W}}=\dot{W}_{\text {net,çlkan }}$

$\varepsilon=\left(h-h_{0}\right)-T_{0}\left(s-s_{0}\right)$

$\dot{\mathrm{S}}_{\text {giren }}+\dot{\mathrm{S}}_{\text {üretim }}=\dot{\mathrm{S}}_{\text {çkan }}$

Burada 0 alt indisi referans şartlarını göstermektedir. Sistemin birinci (termal) ve ikinci yasa (ekserji) verimleri şu şekilde hesaplanmıştır. [35]

$\eta_{\mathrm{I}}=\frac{\dot{W}_{\text {net,çlkan }}}{\dot{Q}_{\text {giren }}}$

burada;

$\dot{W}_{\text {net,çlkan }}=\dot{m}\left[\left(h_{3}-h_{4}\right)+\left(h_{5}-h_{6}\right)\right]$

$\dot{Q}_{\text {giren }}=\dot{m}\left[\left(h_{3}-h_{2}\right)+\left(h_{5}-h_{4}\right)\right]$

$\eta_{\text {II }}=\frac{\dot{E}_{\dot{W}_{\text {net, }, \text { glkan }}}}{\dot{\mathrm{E}}_{\dot{Q}_{\text {giren }}}}$

burada;

$\dot{\mathrm{Ex}}_{\dot{W}_{\text {net,çkan }}}=\dot{W}_{\text {net,çlkan }}$

$\dot{\mathrm{Ex}}_{\dot{Q}_{\text {giren }}}=\dot{Q}_{\text {giren }}\left(\frac{\mathrm{T}-\mathrm{T}_{0}}{\mathrm{~T}}\right)$

Ürün ve yakıt ekserjisi kullanılarak incelenen her bir bileşen için genel ekserji balansı Denklem 15'de sunulmuştur. Ayrıca ekserji verimi, yakıt ekserjisi ve incelenen komponentteki ekserji yıkımının toplam ekserji yıkımına oranı aşağıdaki denklemlerde sırasıyla verilmiştir: 
$\dot{E}_{Y, k}=\dot{E}_{\ddot{U}, k}+\dot{E}_{D, k}$

$\varepsilon_{k}=\left(\frac{\dot{E}_{\ddot{U}, k}}{\dot{E}_{Y, k}}\right)=1-\left(\frac{\dot{E}_{D, k}}{\dot{E}_{Y, k}}\right)$

$y_{D, k}=\left(\frac{\dot{E}_{D, k}}{\dot{E}_{F, k}}\right)$

$y_{D, k}^{*}=\left(\frac{\dot{E}_{D, k}}{\dot{E}_{D, \text { toplam }}}\right)$

burada $\dot{E}_{Y, k}, \dot{E}_{\ddot{U}, k}$ ve $\dot{E}_{D, k}$ sırasıyla incelenen bileşendeki yakıtın ekserjisi, ürünün ekserjisi ve ekserji yıkımıdır. $\varepsilon_{k}$, ekserji verimini göstermektedir. $y_{D, k}$ ve $y_{D, k}^{*}$ ise sırasıyla yakıt ekserjisi ve toplam ekserji yıkımı başına olan ekserji yıkım oranlarıdır.

Üstteki eşitlikler sisteme uygulanmış ve her bir komponent için enerji ve ekserji denge denklemleri Tablo 1.'de sunulmuştur.

Tablo 1. Her bir sistem elemanının enerji ve ekserji denge denklemleri

\begin{tabular}{|c|c|c|}
\hline $\begin{array}{l}\text { Sistem } \\
\text { bileşenleri }\end{array}$ & Enerji denge denklemleri & Ekserji denge denklemleri \\
\hline Pompa (POM) & $\dot{W}_{P O M P A}+\dot{m}_{1} h_{1}=\dot{m}_{2} h_{2}$ & $\dot{E} x_{1}+\dot{W}_{P O M P A}=\dot{E} x_{2}+\dot{E} x_{y l k l m, P O M P A}$ \\
\hline $\begin{array}{l}\text { Buharlaştırıcı } \\
\text { (BUH) }\end{array}$ & $\begin{aligned} \dot{m}_{2} h_{2}+\dot{m}_{4} h_{4} & +\dot{m}_{7} h_{7} \\
& =\dot{m}_{3} h_{3}+\dot{m}_{5} h_{5} \\
& +\dot{m}_{8} h_{8}\end{aligned}$ & $\begin{aligned} \dot{E} x_{2}+\dot{E} x_{4}+\dot{E} & x_{7} \\
& =\dot{E} x_{3}+\dot{E} x_{5}+\dot{E} x_{8} \\
& +\dot{E} x_{y l k l m, B U H}\end{aligned}$ \\
\hline $\begin{array}{l}\text { Yüksek basınç } \\
\text { türbini (YBT) }\end{array}$ & $\dot{m}_{3} h_{3}=\dot{m}_{4} h_{4}+\dot{W}_{Y B T}$ & $\dot{E} x_{3}=\dot{E} x_{4}+\dot{W}_{Y B T}+\dot{E} x_{y \imath k \imath m, Y B T}$ \\
\hline $\begin{array}{l}\text { Alçak basınç } \\
\text { türbini (ABT) }\end{array}$ & $\dot{m}_{5} h_{5}=\dot{m}_{6} h_{6}+\dot{W}_{A B T}$ & $\dot{E} x_{5}=\dot{E} x_{6}+\dot{W}_{A B T}+\dot{E} x_{y l k l m, A B T}$ \\
\hline $\begin{array}{l}\text { Yoğuşturucu } \\
\text { (YOĞ) }\end{array}$ & $\dot{m}_{6} h_{6}+\dot{m}_{9} h_{9}=\dot{m}_{1} h_{1}+\dot{m}_{10} h_{10}$ & $\dot{E} x_{6}+\dot{E} x_{9}=\dot{E} x_{1}+\dot{E} x_{10}+\dot{E} x_{y l k \imath m, Y O \breve{G}}$ \\
\hline
\end{tabular}

\section{B. İLERİ EKSERJİ ANALIZİ}

Kimyasal reaksiyonlar, sonlu sıcaklık farkında 1sı transferi, maddelerin karışımı, sürtünmeler ve sonsuz genleşme gibi tüm gerçek işlemler tersinmezdir [16]. Konvansiyonel ekserji analizi, ekserji yıkım oranının miktarını ve herhangi bir komponentteki tersinmezliğin ne kadar olduğunu belirlemeye yarar. Bununla birlikte, bu yöntemle komponentler arasındaki etkileşim açılanamaz ve gerçek geliştirme potansiyeli tahmin edilemez. Komponentleri birbirleriyle etkileşim içinde olan termodinamik sistemlerde, komponentler arasındaki etkileşim dikkate alınmaksızın sistemin optimizasyonunu yapmak için konvansiyonel yaklaşımın kullanılması uygun değildir. Bunun için son yıllarda geliştirilen ve ileri ekserji analizi olarak adlandırılan detaylı bir analize ihtiyaç vardır. İleri ekserji analizi, kaçınılamaz-önlebilir ve içsel-dışsal olmak üzere iki farklı kısma ayrılmaktadır [36]. 
Önlenebilir/Kaçınılamaz: Ekserji yıkımı $\dot{E}_{D, k}$ önlenebilir $\dot{E}_{D, k}^{\text {ÖN }}$ ve kaçınılamaz $\dot{E}_{D, k}^{K A C} \quad$ kısımlara ayrılabilir [16], [37]. Herhangi bir komponetteki ekserji yıkımı, önlenebilir ve kaçınılamaz kısımların toplamına eşittir. Bir sistemin bütün elemanları kaçınılamaz şartlarda çalıştıııldığında her bir eleman için bulunan ekserji yıkımı o elemanın kaçınılamaz ekserji yıkımını göstermektedir. Önlenebilir ekserji yıkımı ise, herhangi bir komponentin gerçek durumda elde edilen ekserji yıkımı değerleriyle kaçınılamaz şartlarda elde edilen ekserji yıkım değerinin farkına eşittir (Eşitlik 20)

$\dot{E}_{D, k}=\dot{E}_{D, k}^{K A C}+\dot{E}_{D, k}^{O N N}$

Ekserji yıkımının önlenebilir ve kaçınılamaz kısımları, komponentlerin geliştirme potansiyelini belirlemek için oldukça gerçekçi bir yaklaşım sağlar. Malzeme özelliklerinden, bulunabilirliğinden ve ayrıca malzeme ve üretim maliyetlerini içeren teknolojik kısıtlamalardan dolayı herhangi bir komponetteki kaçınılamaz ekserji yıkımı azaltılamaz. Komponetteki ekserji yıkımının geri kalanı önlenebilir ekserji yıkımı olarak adlandırılmaktadır. Bu kısım, komponentin dizaynı geliştirilerek azaltılabilir.

Dışsal/İçsel: Diğer yaklaşım ise ekserji yıkımlarının içsel $\dot{E}_{D, k}^{\text {iç }}$ ve dışsal $\dot{E}_{D, k}^{D I S ̧}$ kısımlara ayrılmasıdır [36]. Ekserji yıkımının içsel ve dışsal kısımları, herhangi bir komponentteki ekserji yıkımının kendinden ya da diğer komponentlerden kaynaklandığını ifade eder. İçsel ekserji yıkımı şöyle bulunur: içsel ekserji yıkımının hesaplanacă̆ komponent gerçek şartlarda, geri kalanlar ise ideal şartlarda çalıştırıldığında söz konusu komponent için bulunan ekserji yıkımı o bileşenin içsel ekserji yıkımıdır. Dışsal ekserji yıkımı, o komponentin gerçek şartlardaki ekserji yıkımı ile içsel ekserji yıkımının farkına eşittir. (Eşitlik 19) Bu yaklaşım, çevrimdeki tüm komponentlere uygulandığında bütün içsel ve dışsal ekserji yıkımları bulunabilir. Dışsal ekserji yıkımı, sözkonusu komponentteki tersinmezliklerin diğer komponetlerden kaynaklandığını, içsel ekserji yıkımı ise kendinden kaynaklandığını ifade eder. Bu ekserji yıkımlarının bulunmasıyla çevrimde hangi komponetlere, hangi seviyede odaklanılmasını gerektiğini ortaya koyar.

$\dot{E}_{D, k}=\dot{E}_{D, k}^{i C}+\dot{E}_{D, k}^{D I S}$

\section{ARASTIRMA BULGULARI}

Hesaplamalar, Mühendislik Denklem Çözücüsü (EES) yazılımının yardımıyla yapılmıştır. Çevre sıcaklığ 1 ve basıncı sırasıyla $27{ }^{\circ} \mathrm{C}$ ve $101.325 \mathrm{kPa}$ olarak alınmıştır. Yoğuşturucu $\left(P_{1}=P_{6}\right)$, buharlaştırıcı $\left(P_{2}=P_{3}\right)$, ara 1sıtma $\left(P_{4}=P_{5}\right)$ ve jeotermal su basınçları sırasılyla $500 \mathrm{kPa}, 3000 \mathrm{kPa}$, 1500 ve $600 \mathrm{kPa}$ olup pompa ve türbinlerin izantropik verimleri \%85 olarak kabul edilmiştir [5]. Akışkanın çalışma basınçları kritik basıncın altında seçilmiştir [38]. ORÇ'deki akışkanın kütlesel debisi $10 \mathrm{~kg} / \mathrm{s}$, yüksek ve alçak basınç türbini giriş sıcaklıkları ise $130^{\circ} \mathrm{C}$ olarak belirlenmiştir. Soğutma suyunun yoğuşturucuya giriş ve çıkış sıcaklı̆̆ sırasıyla $20^{\circ} \mathrm{C}$ ve $25^{\circ} \mathrm{C}$, jeotermal suyunun buharlaştırıcıya giriş ve çıkış sıcaklıkları ise $145^{\circ} \mathrm{C}$ ve $75^{\circ} \mathrm{C}$ ' dir.

Tablo 2'de sistemdeki her bir komponent için gerçek, ideal ve kaçınılamaz şartlardaki çevrim değerleri sunulmuştur. Gerçek ve kaçınılamaz şartlar, ileri ekserji analizindeki önlenebilir/kaçınılamaz kısımlarını bulmak için kullanılır. Gerçek ve ideal şartlar ise içsel/dışsal kısımları bulmak için 
kullanılır. Kaçınılamaz çevrim şartları gerçek ve ideal şartlar arasındadır. Kaçınılamaz durumun hesaplanmasındaki değerler ideal durumdakine yakın alınır. Buharlaştırıcı ve yoğuşturucunun gerçek ve kaçınılamaz basınç farkı değerleri $\left(\triangle P_{B U H}\right.$ ve $\left.\Delta P_{Y O G ̆}\right)$ ideal durum ile arasındaki farka işaret etmektedir.

Tablo 2. Gerçek, ideal ve kaçınılamaz şartlardaki çevrim değerleri

\begin{tabular}{lllll}
\hline Bileşen & Parametre & Gerçek & İdeal & Kaçınılamaz \\
\hline Pompa & $\eta_{\text {POMPA }}$ & $\% 85$ & $\% 100$ & $\% 95$ \\
\hline Buharlaştırıcı & $\Delta P_{B U H}$ & $\% 0.8$ & İzantropik & $\% 0.5$ \\
\hline Yüksek basınç türbini & $\eta_{\text {YBT }}$ & $\% 85$ & $\% 100$ & $\% 90$ \\
\hline Alçak basınç türbini & $\eta_{\text {ABT }}$ & $\% 85$ & $\% 100$ & $\% 90$ \\
\hline Yoğuşturucu & $\Delta P_{\text {YOĞ }}$ & $\% 1.6$ & $\% 0$ & $\% 1$ \\
\hline
\end{tabular}

Tablo 3-5 sırasıyla gerçek, ideal ve kaçınılamaz çalışma şartlarında ORÇ’nin farklı noktalarındaki termodinamik özellikleri göstermektedir. Buharlaştırıcıdaki ve yoğuşturucudaki basınç düşüşü hem gerçek hem de kaçınılamaz çevrimde göz önüne alınmıştır. Gerçek, ideal ve kaçınılamaz şartlar Tablo 2 'de belirtilen değerler kullanılarak hesaplanmıştır. Spesifik ekserjinin negatif değeri, hesaplama şartlarının referans sıcaklığından daha düşük bir sıcaklığa sahip olduğundan kaynaklanmaktadır. Tablolardaki son iki sütun, çevrimin her bir noktasındaki ekserji değerlerini göstermektedir.

Tablo 3. Sistemin gerçek şartlar altındaki termodinamik özellikleri

\begin{tabular}{llllllll}
\hline Nokta & $\mathbf{T}\left({ }^{\circ} \mathbf{C}\right)$ & $\mathbf{P}(\mathbf{k P a})$ & $\mathbf{h}(\mathbf{k J} / \mathbf{k g})$ & $\dot{\mathbf{m}}(\mathbf{k g} / \mathbf{s})$ & $\mathbf{s}(\mathbf{k J} / \mathbf{k g K})$ & $\mathbf{e}(\mathbf{k J} / \mathbf{k g})$ & $\dot{\mathbf{E}} \mathbf{( k W )}$ \\
\hline 1 & 19.13 & 500 & 233.4 & 10 & 19.13 & 500 & 233.4 \\
\hline 2 & 20.62 & 3000 & 236.6 & 10 & 20.62 & 3000 & 236.6 \\
\hline 3 & 130 & 3000 & 617.9 & 10 & 130 & 3000 & 617.9 \\
\hline 4 & 96.16 & 1500 & 595.2 & 10 & 96.16 & 1500 & 595.2 \\
\hline 5 & 130 & 1500 & 643.3 & 10 & 130 & 1500 & 643.3 \\
\hline 6 & 86.96 & 500 & 602.5 & 10 & 86.96 & 500 & 602.5 \\
\hline 7 & 160 & 600 & 2759 & 1.756 & 160 & 600 & 2759 \\
\hline 8 & 75 & 600 & 314.4 & 1.756 & 75 & 600 & 314.4 \\
\hline 9 & 20 & 101.3 & 83.93 & 176.5 & 20 & 101.3 & 83.93 \\
\hline 10 & 25 & 101.3 & 104.8 & 176.5 & 25 & 101.3 & 104.8 \\
\hline
\end{tabular}

Tablo 4. Sistemin ideal şartlar altındaki termodinamik özellikleri

\begin{tabular}{llllllll}
\hline Nokta & $\mathbf{T}\left({ }^{\circ} \mathbf{C}\right)$ & $\mathbf{P}(\mathbf{k P a})$ & $\mathbf{h}(\mathbf{k J} / \mathbf{k g})$ & $\dot{\mathbf{m}}(\mathbf{k g} / \mathbf{s})$ & $\mathbf{s}(\mathbf{k J} / \mathbf{k g K})$ & $\mathbf{e}(\mathbf{k J} / \mathbf{k g})$ & $\dot{\mathbf{E}}(\mathbf{k W})$ \\
\hline 1 & 19.64 & 508 & 234.3 & 10 & 1.12 & 64.89 & 648.9 \\
\hline 2 & 20.87 & 3024 & 237.1 & 10 & 1.12 & 67.64 & 676.4 \\
\hline 3 & 130 & 3024 & 617.5 & 10 & 2.194 & 125.8 & 1258 \\
\hline 4 & 92.9 & 1500 & 590.5 & 10 & 2.194 & 98.86 & 988.6 \\
\hline 5 & 130 & 1500 & 643.3 & 10 & 2.331 & 110.4 & 1104 \\
\hline 6 & 81.82 & 508 & 596 & 10 & 2.331 & 63.11 & 631.1 \\
\hline 7 & 160 & 600 & 2759 & 1.772 & 6.766 & 733.8 & 1300 \\
\hline 8 & 75 & 600 & 314.4 & 1.772 & 1.015 & 15.03 & 26.62 \\
\hline 10 & 20 & 101.3 & 83.93 & 172.9 & 0.2962 & 0.3468 & 59.98 \\
\hline
\end{tabular}


Tablo 5. Sistemin kaçınılamaz şartlar altındaki termodinamik özellikleri

\begin{tabular}{llllllll}
\hline Nokta & $\mathbf{T}\left({ }^{\circ} \mathbf{C}\right)$ & $\mathbf{P}(\mathbf{k P a})$ & $\mathbf{h}(\mathbf{k J} / \mathbf{k g})$ & $\dot{\mathbf{m}}(\mathbf{k g} / \mathbf{s})$ & $\mathbf{s}(\mathbf{k J} / \mathbf{k g K})$ & $\mathbf{e}(\mathbf{k J} / \mathbf{k g})$ & $\dot{\mathbf{E}}(\mathbf{k W})$ \\
\hline 1 & 19.32 & 502.9 & 233.7 & 10 & 1.118 & 64.9 & 649 \\
\hline 2 & 20.62 & 3009 & 236.6 & 10 & 1.119 & 67.63 & 676.3 \\
\hline 3 & 130 & 3009 & 617.8 & 10 & 2.195 & 125.8 & 1258 \\
\hline 4 & 95.06 & 1500 & 593.6 & 10 & 2.203 & 99.43 & 994.3 \\
\hline 5 & 130 & 1500 & 643.3 & 10 & 2.331 & 110.4 & 1104 \\
\hline 6 & 85.25 & 502.9 & 600.4 & 10 & 2.345 & 63.44 & 634.4 \\
\hline 7 & 160 & 600 & 2759 & 1.762 & 6.766 & 733.8 & 1293 \\
\hline 8 & 75 & 600 & 314.4 & 1.762 & 1.015 & 15.03 & 26.48 \\
\hline 9 & 20 & 101.3 & 83.93 & 175.3 & 0.2962 & 0.3468 & 60.8 \\
\hline 10 & 25 & 101.3 & 104.8 & 175.3 & 0.3669 & 0.028 & 4.908 \\
\hline
\end{tabular}

Tablo 6'da ideal, gerçek ve kaçınılamaz durumlar için net güç, 1s1, enerji verimi ve ekserji verimi gösterilmiştir. Tablodan görüldügü gibi, türbinin izantropik veriminin diğer şartlara göre daha düşük olmasından dolayı gerçek çevrimdeki net iş çıkışı da düşük olmaktadır. Hem enerji verimi (Net iş çıkışının 1S1 girişine bölümü olarak adlandırılır) hem de ekserji verimi (Net iş çıkışının buharlaştırıcıdaki yakıt ekserjisine bölümü olarak adlandırılır) ideal çevrimde en yüksek değerine sahiptir. İdeal durumda enerji verimi \%16.51 iken kaçınılamaz şartlarda teknolojik engeller nedeniyle verim \%14.9 değerini almıştır. Gerçek çevrimde ise bu verim değeri \%14.04 olmuştur.

Konvansiyonel ekserji denklemleri her bir komponente uygulanıp ve aşağıdaki sonuçlar elde edilmiştir. Toplam yakıt ekserji oranı buharlaştırıcıya giren jeotermal suyun ekserjisiyle çıkan R152a'nın ekserjileri arasındaki farka eşittir. Toplam ürün ekserji oranı ise, türbinlerdeki net iş çıkışına eşittir. Tablo 7-9'da AIORÇ sisteminin sırasıyla gerçek, ideal ve kaçınılamaz şartlar altında konvansiyonel ekserji analizinin sonuçları sunulmuştur. Gerçek şartlardaki konvansiyonel analizden elde edilen sonuçlara göre (Tablo 7) komponentlerdeki ekserji yıkımları en yüksekten düşüğe doğru sırasıyla şu şekilde gerçekleşmiştir: buharlaştırıcı $(574.6 \mathrm{~kW})$, yüksek basınç türbini $(60.48 \mathrm{~kW})$, yoğuşturucu $(43.9 \mathrm{~kW})$, yüksek basınç türbini $(32.71 \mathrm{~kW})$ ve pompa $(5.019 \mathrm{~kW})$. Sistem verimi arttırmak için ekserji yıkım oranının azaltılması gereklidir. Konvansiyonel analizinden tersinmezliklerin diğer komponentler mi yoksa komponentin kendisinden mi kaynaklandığını tespit etmek mümkün değildir. Bu nedenle sistem komponentleri arasındaki etkileşimi ve her bir komponentin gerçek geliştirme potansiyelini belirlemek için ileri ekserji analizi yapmak gereklidir [14].

Tablo 6. İdeal, kaçınılamaz ve gerçek çevrimlerin güç ve verimleri

\begin{tabular}{llll}
\hline & İdeal & Kaçınılamaz & Gerçek \\
\hline$\dot{W}_{\text {POMPA }}(\mathrm{kW})$ & 27.58 & 28.89 & 32.19 \\
\hline$\dot{W}_{\text {TÜRBं } N}(\mathrm{~kW})$ & 742.8 & 671 & 635 \\
\hline$\dot{W}_{N E T}(\mathrm{~kW})$ & 715.2 & 642.1 & 602.81 \\
\hline$\dot{Q}_{B U H}(\mathrm{~kW})$ & 4332 & 4308 & 4294 \\
\hline$\dot{Q}_{Y O \breve{~}}(\mathrm{~kW})$ & 3617 & 3666 & 3692 \\
\hline$\dot{\mathrm{E} B U H}(\mathrm{~kW})$ & 1274 & 1267 & 1262 \\
\hline$\eta_{\text {sistem }}(\%)$ & 16.51 & 14.9 & 14.04 \\
\hline$\varepsilon_{\text {sistem }}(\%)$ & 56.15 & 50.69 & 47.75 \\
\hline
\end{tabular}


Tablo 7. Gerçek şartlar altında konvansiyonel ekserji analizi sonuçları

\begin{tabular}{lllllll}
\hline Komponent & $\dot{\mathbf{E F}}(\mathbf{k W})$ & $\dot{\mathbf{E P}}(\mathbf{k W})$ & $\dot{\mathbf{E Y}}(\mathbf{k W})$ & $\mathbf{\varepsilon ( \% )}$ & Yk (\%) & Yk* $^{*}(\boldsymbol{\%})$ \\
\hline Pompa & 681.3 & 676.2 & 5.019 & 99.26 & 0.7368 & 0.7011 \\
\hline Buharlaştırıc1 & 2962 & 2388 & 574.6 & 80.6 & 19.4 & 80.26 \\
\hline Yüksek Basınç türbini & 1257 & 1224 & 32.71 & 97.4 & 2.602 & 4.569 \\
\hline Alçak basınç türbini & 1104 & 1044 & 60.48 & 94.52 & 5.477 & 8.447 \\
\hline Yoğuşturucu & 697.1 & 654 & 43.1 & 93.82 & 6.182 & 6.02 \\
\hline Sistem & 1262 & 602.8 & 715.9 & 47.75 & 56.71 & 100 \\
\hline
\end{tabular}

Tablo 8. Ideal şartlar altında konvansiyonel ekserji analizi sonuçları

\begin{tabular}{lllllll}
\hline Komponent & $\dot{\mathbf{E F}} \mathbf{( k W )}$ & $\dot{\mathbf{E P}}(\mathbf{k W})$ & $\dot{\mathbf{E}} \mathbf{Y}(\mathbf{k W})$ & $\boldsymbol{\varepsilon} \mathbf{( \% )}$ & Yk (\%) & Yk*(\%) \\
\hline Pompa & 676.5 & 676.4 & 0.08502 & 100 & 0.01 & 0.01 \\
\hline Buharlaştırıc1 & 2965 & 2389 & 576.2 & 80.57 & 19.43 & 93.91 \\
\hline Yüksek Basınç türbini & 1258 & 1258 & 0 & 100 & 0 & 0 \\
\hline Alçak basınç türbini & 1104 & 1104 & 0 & 100 & 0 & 0 \\
\hline Yoğuşturucu & 691.1 & 653.8 & 37.29 & 94.6 & 5.40 & 6.08 \\
\hline Sistem & 1274 & 715.2 & 613.6 & 56.15 & 48.18 & 100 \\
\hline
\end{tabular}

Tablo 9. Kaçınılamaz şartlar altında konvansiyonel ekserji analizi sonuçları

\begin{tabular}{lllllll}
\hline Komponent & $\dot{\boldsymbol{E}}_{\mathbf{F}}(\mathbf{k W})$ & $\dot{\boldsymbol{E}}_{\mathbf{P}}(\mathbf{k W})$ & $\dot{\boldsymbol{E}}_{\mathbf{Y}}(\mathbf{k W})$ & $\boldsymbol{\varepsilon}(\boldsymbol{\%})$ & $\mathbf{Y}_{\mathbf{k}}(\boldsymbol{\%})$ & $\mathbf{Y}_{\mathbf{k}}{ }^{*}(\boldsymbol{\%})$ \\
\hline Pompa & 677.9 & 676.3 & 1.56 & 99.77 & 0.2301 & 0.2293 \\
\hline Buharlaştırıc1 & 2964 & 2388 & 575.5 & 80.58 & 19.42 & 84.58 \\
\hline Yüksek Basınç türbini & 1258 & 1236 & 21.91 & 98.26 & 1.743 & 3.221 \\
\hline Alçak basınç türbini & 1104 & 1064 & 40.19 & 96.36 & 3.64 & 5.907 \\
\hline Yoğuşturucu & 695.2 & 653.9 & 41.25 & 94.07 & 5.934 & 6.062 \\
\hline Sistem & 1267 & 642.1 & 680.4 & 50.69 & 53.72 & 100 \\
\hline
\end{tabular}

Tablo 10. Ileri ekserji analizi sonuçları $(\mathrm{kW})$

\begin{tabular}{llllll}
\hline Komponent & $\dot{\mathbf{E}}_{\mathbf{Y}}$ & $\dot{\mathbf{E}}_{\mathbf{Y}}^{\text {IC }}$ & $\dot{\mathbf{E}}_{\mathbf{Y}}^{\text {DIŞ }}$ & $\dot{\mathbf{E}}_{\mathbf{Y}}^{\text {KAC }}$ & $\dot{\mathbf{E}}_{\mathbf{Y}}^{\text {ON }}$ \\
\hline Pompa & 5.02 & 5.02 & 0 & 1.56 & 3.46 \\
\hline Buharlaştırıc1 & 574.6 & 574.6 & 0 & 574.6 & 0 \\
\hline Yüksek Basınç türbini & 32.71 & 0 & 32.71 & 21.91 & 10.8 \\
\hline Alçak basınç türbini & 60.48 & 0 & 60.48 & 40.19 & 20.29 \\
\hline Yoğuşturucu & 43.1 & 37.29 & 5.81 & 41.25 & 1.85 \\
\hline Sistem & 715.9 & 620 & 95.92 & 680.4 & 36.4 \\
\hline
\end{tabular}

Tablo 10'da ileri ekserji analizi sonuçları verilmiştir. Konvansiyonel ekserji analizi sonuçlarına göre toplam ekserji yıkımının yaklaşık \%89'u buharlaştırıcı ve alçak basınç türbininde meydana gelmiştir. Geri kalan ekserji yıkımı pompa, yoğuşturucu ve yüksek basınç türbininde gerçekleşmiştir. Bununla birlikte buharlaştırıcıdaki ekserji yıkımının tamamı kaçınılmaz kısmına aittir. Türbinler hariç diğer komponentlerde içsel ekserji yıkımları dışsal kısımdan daha büyüktür. Bu nedenle her bir 
komponentin ekserji yıkımına en büyük etkiyi, komponentin kendi içindeki tersinmezliklerden kaynaklandığı söylenebilir. En yüksek içsel ekserji yıkımına sahip komponent \%92.7 ile buharlaştırıcıdır $(574.6 \mathrm{~kW})$. Bundan dolayı, buharlaştırıcının verimindeki artış, bu elemanın ekserji yıkımını azaltır ve dolayısıyla toplam sistem veriminde bir iyileşme sağlar. Ayrıca tüm sistem büyük oranda içsel (\%86.6) ve kaçınılamaz (\%95) ekserji yıkımlarına sahiptir.

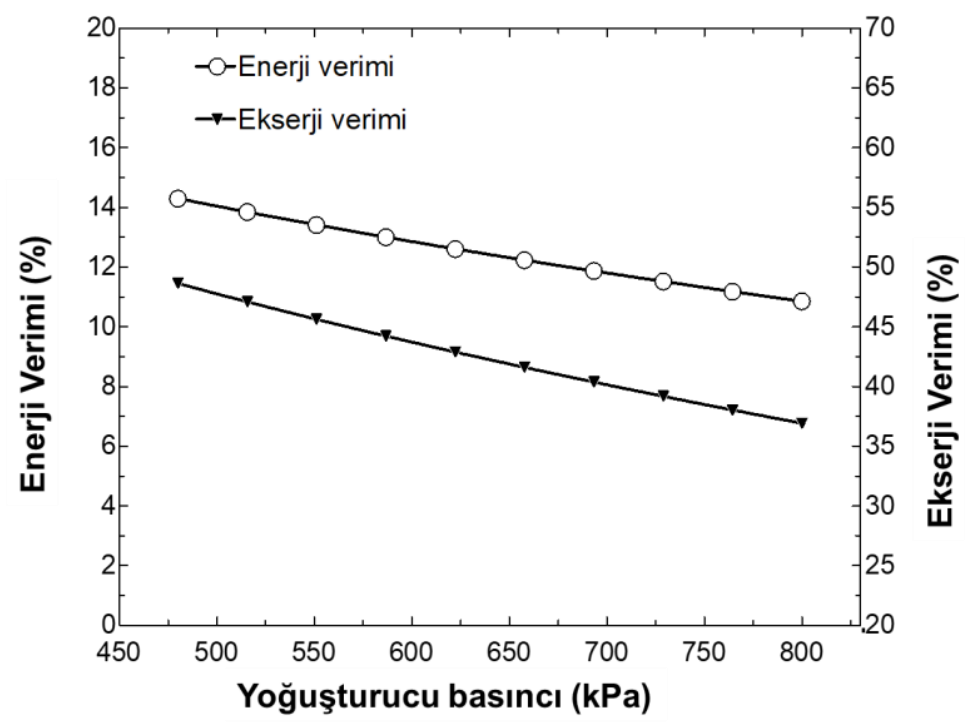

Şekil 2. Yoğuşturucu basıncinın enerji ve ekserji verimi üzerindeki etkisi

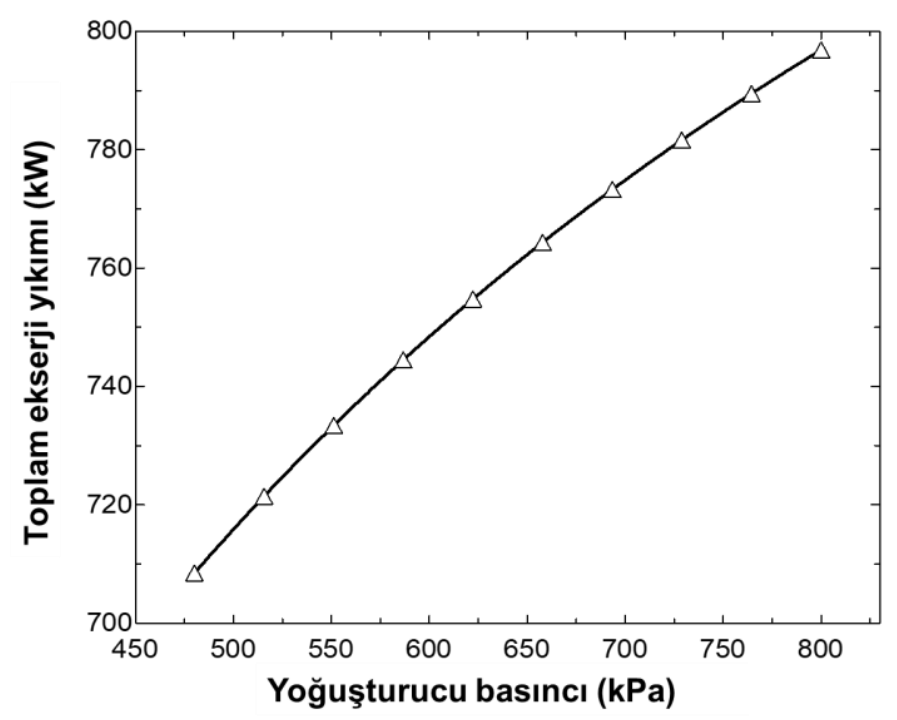

Şekil 3. Yoğuşturucu basıncının toplam ekserji yıkımı üzerindeki etkisi

Şekil 2-5'te sırasıyla yoğuşturucu ve buharlaştırıcı basınçlarının enerji ve ekserji verimleri ile toplam ekserji yıkımı üzerindeki etkisi incelenmiştir. Bu sonuçlar, konvansiyonel ekserji analizinin parametrik çalışma sonuçlarıdır. Şekil 2 ve 3'te yoğuşturucu basıncının bahsedilen etkisi görülmüştür. Şekil 2'de görüldüğü gibi yoğuşturucu basıncının artmasıyla verimler azalırken ekserji yıkımı artmaktadır. Basınçtaki $320 \mathrm{kPa}$ 'lık bir artış enerji ve ekserji veriminde sırasıyla \%3.45 ve \%11.72'lik azalmaya neden olmuştur. Ekserji verimindeki azalış, enerji verimine göre daha hızlıdır. Basınç $480 \mathrm{kPa}$ iken enerji ve ekserji verimleri sırasıyla $\% 14.3$ ve $\% 48.63$, basınç $800 \mathrm{kPa}$ olduğunda sırasıyla $\% 10.85$ ve 
\%36.91 değerlerini alır. Basıncın $480 \mathrm{kPa}$ 'dan $800 \mathrm{kPa}$ 'a çıkmasıyla toplam ekserji yıkımında 88.3 kW'l1k bir artış meydana gelmiştir.

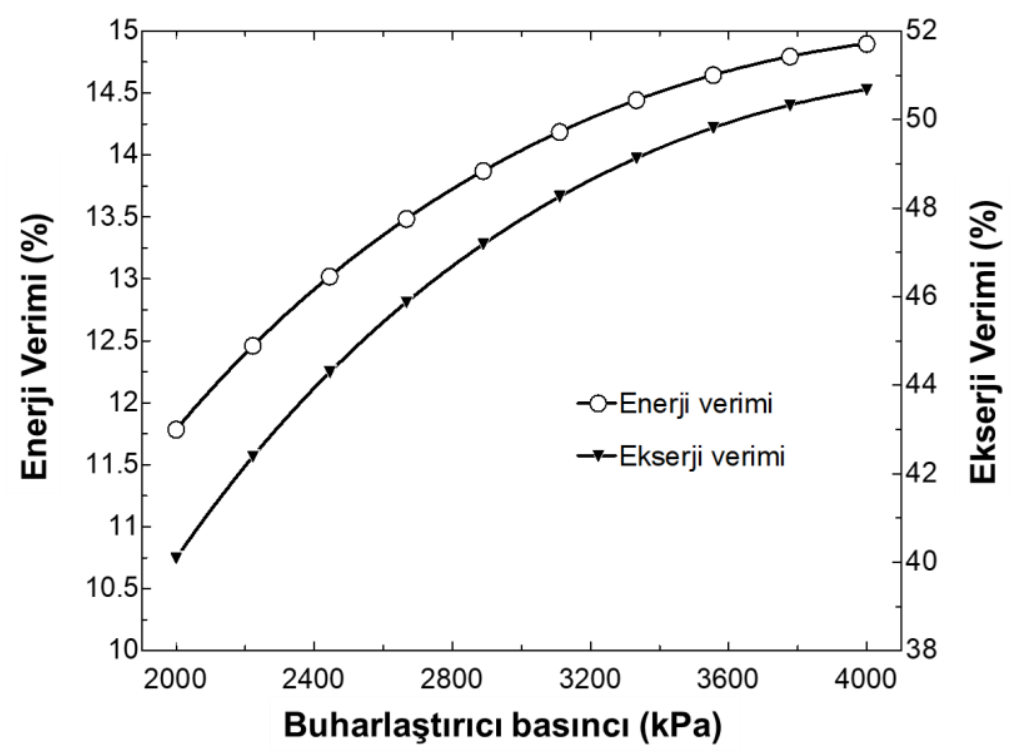

Şekil 4. Buharlaştırıcı basıncının enerji ve ekserji verimi üzerindeki etkisi

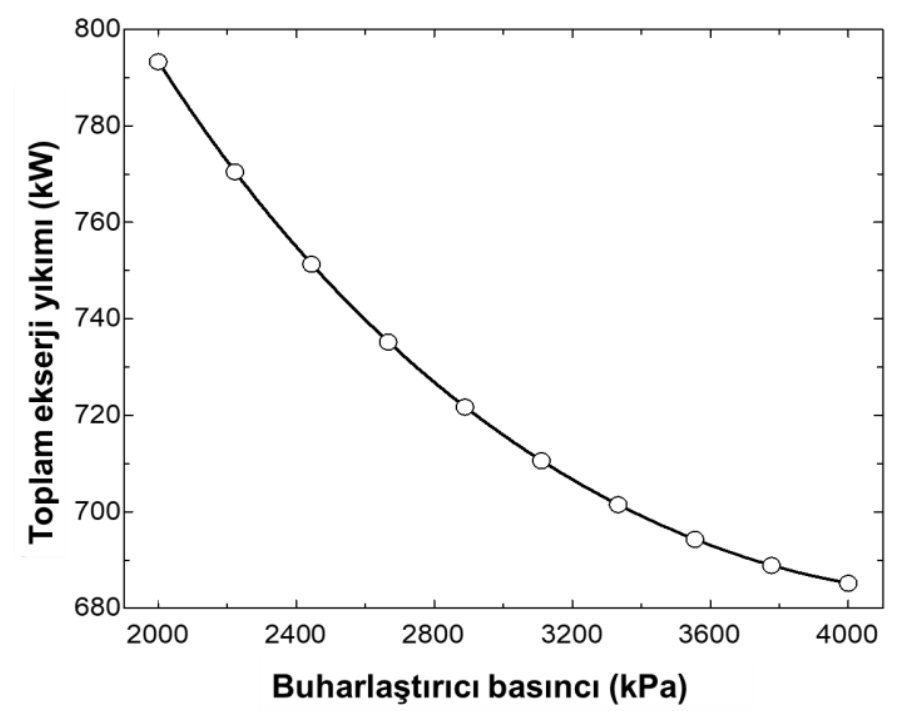

Şekil 5. Buharlaştırıcı basıncının toplam ekserji yıkımı üzerindeki etkisi

Şekil 4 ve 5'te buharlaştırıcı basıncının enerji verimi, ekserji verimi ve toplam ekserji yıkımı üzerindeki etkisi sunulmuştur. Buharlaştırıcı basıncıyla verimler doğru orantılıyken ekserji yıkımı ters orantılıdır. Enerji ve ekserji verimlerinin artış eğilimleri birbirlerine çok benzerdir. Buharlaştırıcı basınc1 $2000 \mathrm{kPa}$ iken enerji ve ekserji verimleri sırasıyla \%11.79 ve \%40.09 değerlerini alır. Basınç $4000 \mathrm{kPa}$ olduğunda verimler sırasıyla \%14.9'a ve \%50.68'e yükselir. Buharlaştırıcının basıncının $2000 \mathrm{kPa}$ artmasıyla sistemdeki toplam ekserji yıkımında yaklaşık \%14'lük bir azalma meydana gelir ki bu da sistemin ekserji veriminin \%10.59 artmasını sağlar. Sistemdeki en yüksek ve en düşük ekserji yıkımı sırasıyla $793.3 \mathrm{~kW}$ ve $685.3 \mathrm{~kW}$ olarak gerçekleşmiştir. 


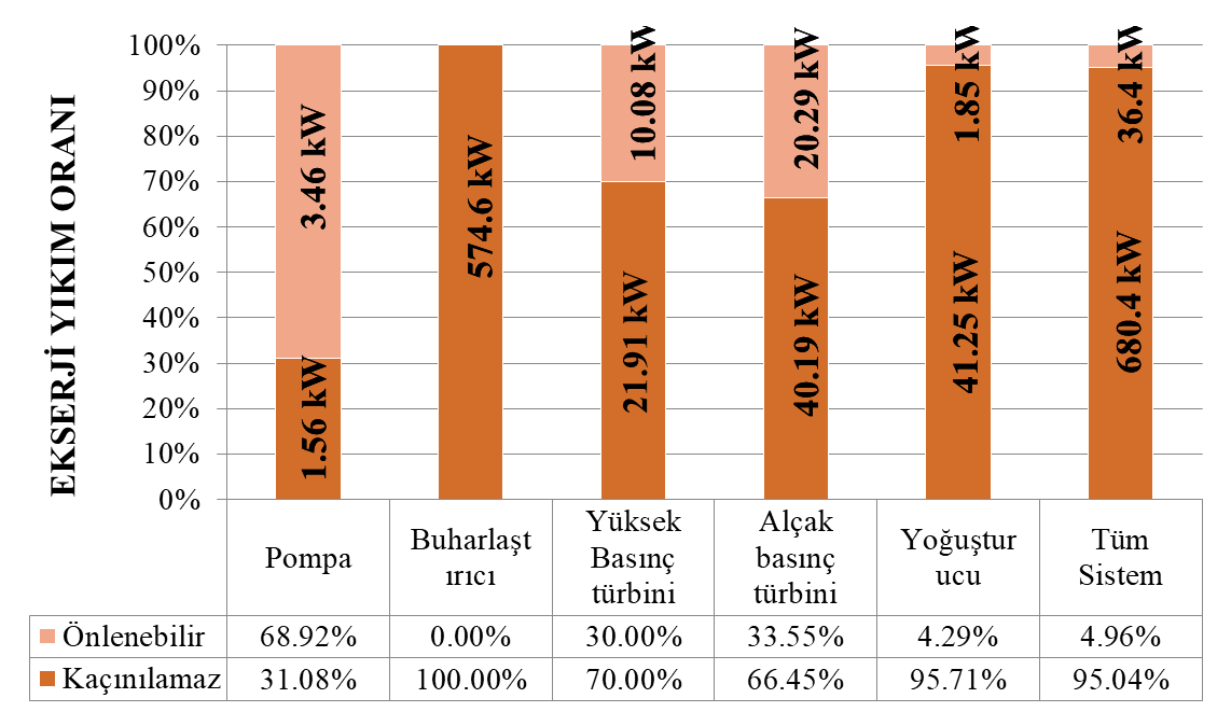

Şekil 6. Önlenebilir ve kaçınılamaz ekserji yıkımlarının her bir komponentteki yüzdesi

Şekil 6'de farklı komponetlerdeki önlenebilir ve kaçınılmaz ekserji yıkımların yüzdesi ve miktarı karşılaştırmalı olarak sunulmuştur. Sistemdeki ekserji yıkımı çok büyük oranda (\%95.04) kaçınılamazdır. Bu nedenle sistem verimini iyileştirmek için komponentlerden hangisine, hangi oranda odaklanılması gerektiği çok büyük önem arzetmektedir. Buharlaştırıcı en yüksek ekserji yıkım oranına sahip olmasına rağmen, ekserji yıkımının tamamı kaçınılamaz kısmına aittir. Diğer bir deyişle, buharlaştırıcıdaki geliştirme potansiyeli sıfırdır. Türbinlerdeki ekserji yıkımı, toplam ekserji yıkımının \%12.9'una eşit olmasına rağmen, bu komponentlerdeki önlenebilir kısımlar toplam önlenebilir kısmın \%84.6'üne sahiptir (yüksek basınç türbini - $10.08 \mathrm{~kW}$ ve alçak basınç türbini - $20.29 \mathrm{~kW}$ ). Pompadaki önlenebilir kısım \%68.92 olmasına rağmen miktarı çok düşüktür (3.46 kW).

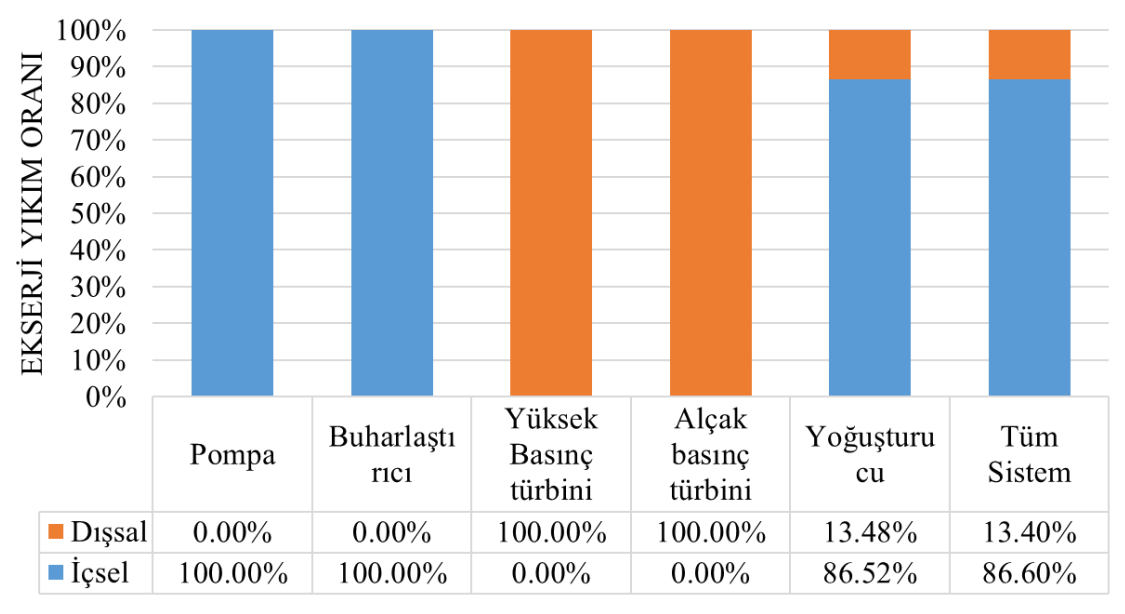

Şekil 7. İçsel ve dışsal ekserji yıkımlarının her bir komponentteki yüzdesi

Şekil 7'da farklı komponetlerdeki içsel ve dışsal ekserji yıkımlarının yüzdesi ve miktarı karşılaştırmalı olarak sunulmuştur. Tüm sisteme bakıldığında içsel ekserji yıkım yüzdesinin $\% 86.60$ olduğu görülmektedir. Pompa ve buharlaştırıcıdaki ekserji yıkımlarının tamamı içsel kısma aittir. Yoğuşturucudaki ekserji yıkımının içsel kısmının yüzdesi, dışsal kısımdan çok daha büyüktür (\%86.52 ve \%13.40). Yüksek basınç ve alçak basınç türbinlerindeki ekserji yıkımlarının tamamı dışsal kısma 
aittir. Yani pompa, buharlaştırıcı ve yoğuşturucudaki iyileştirme sistem veriminde olumlu etki yapacaktır.

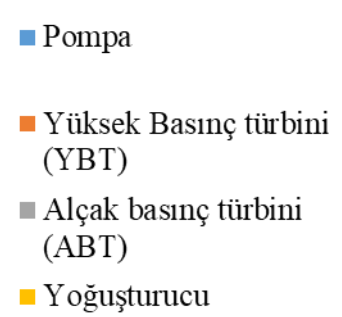

- Pompa

Yüksek Basınç türbini

Yoğuşturucu

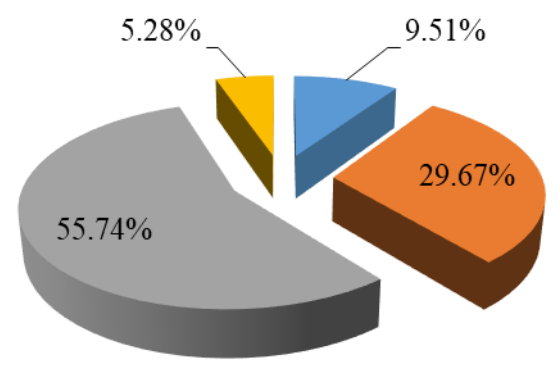

Şekil 8. Toplam önlenebilir ekserji yıkımı miktarındaki her bir komponentin yüzdesi

Şekil 10'da toplam önlenebilir ekserji yıkım miktarındaki her bir komponentin yüzdesi gösterilmiştir. Toplam önlenebilir kısımda en yüksek yüzdeye sahip komponent alçak basınç türbini olduğu için, sistem performansını geliştirmek için ilk olarak odaklanılması gereken komponent budur. $\mathrm{Bu}$ komponenti \%29.67'lik oranla yüksek basınç türbini takip etmektedir. Bu iki komponentin geliştirme potansiyeli, toplam önlenebilir kısmın \%85.41'ine eşittir. Yoğuşturucudaki tersinmezlik (43.1 kW) pompadakine $(5.02 \mathrm{~kW})$ oranla çok daha büyük olmasına rağmen, pompadaki önlenebilir kısım (3.46 $\mathrm{kW}-\% 9.51)$ yoğuşturucudakinden $(1.85 \mathrm{~kW}-\% 5.28)$ daha fazladır.

\section{SONUCLLAR}

$\mathrm{Bu}$ çalışmada, jeotermal kaynaklı ara 1sıtmalı organik Rankine çevriminin konvansiyonel ve ileri ekserji analizleri gerçekleştirilmiştir. Analizler Mühendislik Denklem Çözücüsü (EES) yardımıyla yapılmış olup iş akışkanı olarak R152a kullanılmıştır. Çalışmada öncelikle konvansiyonel analiz yapılmış, buharlaştırıcı ve yoğuşturucu basınçlarının enerji verimi, ekserji verimi ve toplam ekserji yıkımı üzerindeki etkisi incelenmiştir. Ayrıca, sistemdeki komponentlerin birbiri arasındaki etkileşimi ve sistemin geliştirilme potansiyelini belirlemek için ileri ekserji analizi yapılmıştır. Bunları belirlemek için de ekserji yıkımları içsel/dışsal ve önlenebilir/kaçınılamaz kısımlara ayrılmıştır. Aşağıdaki maddeler çalışmayı özetlemektedir.

1. Yoğuşturucu basıncının artması sistem verimi üzerinde olumsuz etkiye sahipken buharlaştırıcı basıncının artmasıyla verimler de artar. Basınçlar, toplam ekserji yıkımları üzerinde ise ters etkiye sahiptir.

2. En yüksek ekserji yıkımı buharlaştırıcıda meydana gelmiştir ve bunu alçak basınç türbini takip etmektedir. Bu iki komponentteki ekserji yıkımı toplam ekserji yıkımının \%89'una eşittir. Ekserji yıkımları en yüksekten düşüğe doğru sırasıyla buharlaştırıcı $(574.6 \mathrm{~kW})$, yüksek basınç türbini (60.48 $\mathrm{kW})$, yoğuşturucu $(43.9 \mathrm{~kW})$, yüksek basınç türbini $(32.71 \mathrm{~kW})$ ve pompa $(5.019 \mathrm{~kW})$ şekilde gerçekleşmiştir.

3. $500 \mathrm{kPa}$ yoğuşturucu ve $3000 \mathrm{kPa}$ buharlaştırıcı basıncında sistemin enerji ve ekserji verimleri sirasıyla \%14.04 ve \%50.69 olarak bulunmuştur.

4. Tüm sistem büyük oranda içsel (\%86.6) ve kaçınılamaz (\%95.04) ekserji yıkımlarına sahiptir. Diğer bir deyişle sistemin yaklaşık sadece $\% 5$ 'lik bir geliştirme potansiyeli olduğu söylenebilir. 
5. Tüm sistemin büyük bir kısmının (\%86.60) içsel ekserji yıkımına sahip olduğu görülmektedir. Ayrıca, pompa ve buharlaştırcıdaki tersinmezliklerin tamamı içsel iken, türbinlerdeki tersinmezliklerin tamamını diğer komponentlerden kaynaklanmaktadır.

6. Buharlaştırıcının içsel ekserji yıkımının toplam içsel kısımdaki oranı \%92.7'dir (574.6 kW). Bu nedenle buharlaştırıcının modifikasyonu ile sistem veriminde gelişme sağlanabilir.

7. En yüksek tersinmezliğe sahip komponent buharlaştırıcı olmasına rağmen, bu komponentteki tersinmezliklerin hepsi kaçınılamaz kısmına aittir.

8. Türbinlerdeki ekserji yıkımı düşük olmasına rağmen bu komponentlerdeki önlenebilir kısım en yüksek orana sahiptir.

9. Alçak ve yüksek basınç türbinlerinin toplam önlenebilir ekserji yıkımındaki yüzdeleri sırasıyla $\% 55.74$ ve \%29.6'dır. Bu nedenle bu komponentlerin tersinmezliklerindeki azalma sistem veriminde artışa sebep olabilecektir.

\section{KAYNAKLAR}

[1] A. Ustaoglu, J. Okajima, X. R. Zhang, ve S. Maruyama, "Assessment of a solar energy powered regenerative organic Rankine cycle using compound parabolic involute concentrator," Energy Convers. Manag., vol. 184, pp. 661-670, Mar. 2019.

[2] R. Şahin, S.Ata, ve A. Kahraman, "Organik Rankine Çevriminde Farklı Tip Akışkanlarda Türbin Giriş Sicaklığı ve Basıncının Sistem Bileşenlerindeki Tersinmezlik Değerlerine Etkisinin Belirlenmesi Determination of Impact of Turbine Input Temperature and Pressure on the Irreversibility Values," Çukurova Üniversitesi Mühendislik-Mimarlık Fakültesi Derg., vol. 33, no. June, pp. 225-236, 2018.

[3] T. K. Gogoi ve K. Talukdar, "Exergy based parametric analysis of a combined reheat regenerative thermal power plant and water- $\mathrm{LiBr}$ vapor absorption refrigeration system," Energy Convers. Manag., vol. 83, pp. 119-132, 2014.

[4] A. Khaliq ve S. C. Kaushik, "Second-law based thermodynamic analysis of Brayton/Rankine combined power cycle with reheat," Appl. Energy, vol. 78, no. 2, pp. 179-197, 2004.

[5] P. Gang, L. Jing, ve J. Jie, "Design and analysis of a novel low-temperature solar thermal electric system with two-stage collectors and heat storage units," Renew. Energy, vol. 36, no. 9, pp. 2324-2333, 2011.

[6] F. Petrakopoulou, G. Tsatsaronis, T. Morosuk, ve A. Carassai, "Conventional and advanced exergetic analyses applied to a combined cycle power plant," Energy, vol. 41, no. 1, pp. 146$152,2012$.

[7] A. Gungor, A. Hepbasli, ve H. Gunerhan, "Enhanced exergy analyses of a gas engine heat pump (GEHP) dryer for medicinal and aromatic plants," Int. J. Exergy, vol. 18, no. 1, pp. 1-21, 2015.

[8] E. Bozoglan, Z. Erbay, A. Hepbasli, ve H. Gunerhan, "Splitting the exergy destructions of an olive oil refining plant into avoidable and unavoidable parts based on actual operational data," Int. J. Exergy, vol. 21, no. 3, p. 277, 2016.

[9] V. Jain, G. Sachdeva, ve S. S. Kachhwaha, "Comparative performance study and advanced exergy analysis of novel vapor compression-absorption integrated refrigeration system," Energy Convers. Manag., vol. 172, no. June, pp. 81-97, 2018. 
[10] E. Gholamian, P. Hanafizadeh, ve P. Ahmadi, "Advanced exergy analysis of a carbon dioxide ammonia cascade refrigeration system," Appl. Therm. Eng., vol. 137, pp. 689-699, 2018.

[11] T. Morosuk ve G. Tsatsaronis, "A new approach to the exergy analysis of absorption refrigeration machines," Energy, vol. 33, no. 6, pp. 890-907, 2008.

[12] S. Gong ve K. Goni Boulama, "Parametric study of an absorption refrigeration machine using advanced exergy analysis," Energy, vol. 76, pp. 453-467, 2014.

[13] A. Ustaoglu, M. Alptekin, M. E. Akay, ve R. Selbaş, "Enhanced exergy analysis of a waste heat powered ejector refrigeration system for different working fluids," Int. J. Exergy, vol. 24, no. $2-4,2017$.

[14] T. Morosuk ve G. Tsatsaronis, "Advanced exergetic evaluation of refrigeration machines using different working fluids," Energy, vol. 34, no. 12, pp. 2248-2258, 2009.

[15] A. Mortazavi ve M. Ameri, "Conventional and advanced exergy analysis of solar flat plate air collectors," Energy, vol. 142, pp. 277-288, 2018.

[16] F. Petrakopoulou, G. Tsatsaronis, T. Morosuk, ve A. Carassai, "Conventional and advanced exergetic analyses applied to a combined cycle power plant," Energy, vol. 41, no. 1, pp. 146$152,2012$.

[17] A. K. Mossi Idrissa ve K. Goni Boulama, "Advanced exergy analysis of a combined Brayton/Brayton power cycle,” Energy, vol. 166, pp. 724-737, 2019.

[18] S. Fellaou ve T. Bounahmidi, "Analyzing thermodynamic improvement potential of a selected cement manufacturing process: Advanced exergy analysis," Energy, vol. 154, pp. 190-200, 2018.

[19] Z. Wang, W. Xiong, D. S. K. Ting, R. Carriveau, ve Z. Wang, "Conventional and advanced exergy analyses of an underwater compressed air energy storage system," Appl. Energy, vol. 180, pp. 810-822, 2016.

[20] M. Fallah, H. Siyahi, R. A. Ghiasi, S. M. S. Mahmoudi, M. Yari, ve M. A. Rosen, "Comparison of different gas turbine cycles and advanced exergy analysis of the most effective," Energy, vol. 116, pp. 701-715, 2016.

[21] H. Nami, A. Nemati, ve F. Jabbari Fard, "Conventional and advanced exergy analyses of a geothermal driven dual fluid organic Rankine cycle (ORC)," Appl. Therm. Eng., vol. 122, pp. 59-70, 2017.

[22] H. Gökgedik, M. Yürüsoy, ve A. Keçebaş, "Improvement potential of a real geothermal power plant using advanced exergy analysis," Energy, vol. 112, pp. 254-263, 2016.

[23] A. Keçebaş ve H. Gökgedik, "Thermodynamic evaluation of a geothermal power plant for advanced exergy analysis," Energy, vol. 88, pp. 746-755, 2015.

[24] O. Özkaraca, A. Keçebaş, ve C. Demircan, "Comparative thermodynamic evaluation of a geothermal power plant by using the advanced exergy and artificial bee colony methods," Energy, vol. 156, pp. 169-180, 2018.

[25] T. Koroglu ve O. S. Sogut, "Conventional and advanced exergy analyses of a marine steam power plant," Energy, vol. 163, pp. 392-403, 2018. 
[26] H. Khosravi, G. R. Salehi, ve M. T. Azad, "Design of structure and optimization of organic Rankine cycle for heat recovery from gas turbine: The use of $4 \mathrm{E}$, advanced exergy and advanced exergoeconomic analysis," Appl. Therm. Eng., vol. 147, pp. 272-290, 2019.

[27] J. Galindo, S. Ruiz, V. Dolz, ve L. Royo-Pascual, "Advanced exergy analysis for a bottoming organic rankine cycle coupled to an internal combustion engine," Energy Convers. Manag., vol. 126, pp. 217-227, 2016.

[28] J. Galindo, S. Ruiz, V. Dolz, ve L. Royo-Pascual, "Advanced exergy analysis for a bottoming organic rankine cycle coupled to an internal combustion engine," Energy Convers. Manag., vol. 126, pp. 217-227, 2016.

[29] ASHRAE, "Designation and Safety Classification of Refrigerants, Addendum $r$ to ANSI/ASHRAE Standard 34-2013," ANSI/ASHRAE Standard 34-2010. 2015.

[30] Ö. Kaşka, "Energy and exergy analysis of an organic Rankine for power generation from waste heat recovery in steel industry," Energy Convers. Manag., vol. 77, pp. 108-117, 2014.

[31] L. Garousi Farshi, A. H. Mosaffa, C. A. Infante Ferreira, ve M. A. Rosen, "Thermodynamic analysis and comparison of combined ejector-absorption and single effect absorption refrigeration systems," Appl. Energy, vol. 133, pp. 335-346, 2014.

[32] Y. a. Çengel, “Thermodynamics: An Engineering Approach,” McGraw-Hill, 2004.

[33] A. Bejan, Advanced Engineering Thermodynamics. 2016.

[34] E. K. Akpinar ve A. Hepbasli, "A comparative study on exergetic assessment of two groundsource (geothermal) heat pump systems for residential applications," Build. Environ., vol. 42, no. 5, pp. 2004-2013, 2007.

[35] M. A. Rosen ve I. Dincer, "Exergy as the confluence of energy, environment and sustainable development," Exergy, An Int. J., vol. 1, no. 1, pp. 3-13, 2001.

[36] T. Morosuk, G. Tsatsaronis, ve C. Zhang, "Conventional thermodynamic and advanced exergetic analysis of a refrigeration machine using a Voorhees' compression process," Energy Convers. Manag., vol. 60, pp. 143-151, 2012.

[37] F. Cziesla, G. Tsatsaronis, ve Z. Gao, "Avoidable thermodynamic inefficiencies and costs in an externally fired combined cycle power plant," Energy, vol. 31, no. 10-11, pp. 1472-1489, 2006.

[38] E. W. Lemmon, M. L. Huber, ve M. O. McLinden, "NIST Standard Reference Database 23: Reference Fluid Thermodynamic and Transport Properties (REFPROP), Version 9.0," Phys. Chem. Prop. ..., 2010. 